\title{
The text of the Bible: Hermeneutics, exegesis and interpretation
}

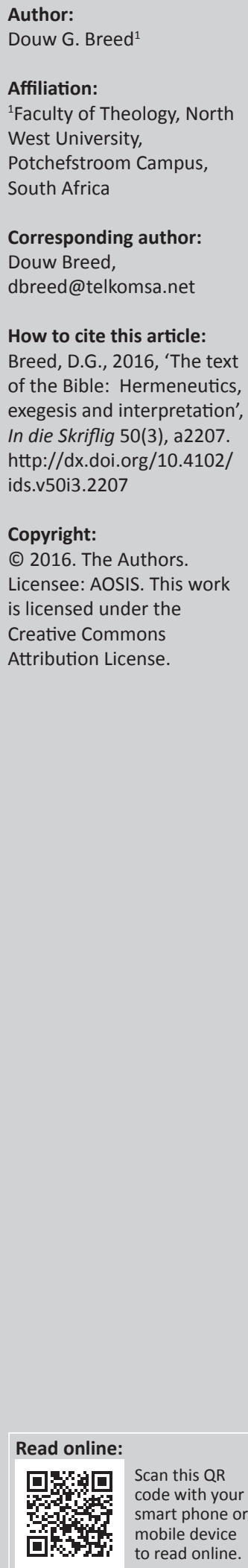

Prof Dr Gert Johannes Cornelis Jordaan reached the age of 65 on 23 February 2016 - the age at which, in terms of the agreement with the NWU, he should retire. Jorrie, as he is generally known, obtained his doctorate in 1979 in Greek with a thesis entitled: 'The adjudication of word-order variants in the Gospel according to Luke'.

Jorrie had an exceptional blessed career. Already in 1979 he became head of the Department of Greek at the former Potchefstroom University for Higher Education (PU for CHE). After he was confirmed as a minister in 1982 and served in two congregations, he was called in 1989 to serve as a professor in New Testament at the Theological School in Potchefstroom (TSP) and the Faculty of Theology of the PU for CHE. He served as vice-rector of the TSP from 2004-2009 and from 20102015 as rector.

In the field of the New Testament study, Jorrie made a special contribution over the years and he enjoys high prestige and recognition on national and international level. Individually, and in concert with other colleagues, he has published 13 books, five chapters in collections and 24 journal articles. In 2011, 2012 and 2013 he received the NWU award for best lecturer in the Faculty of Theology.

Jorrie's dedication in the service of the Lord also emerges from his work in churches, especially in the Reformed Churches in South Africa (RCSA). He served on various deputies of the RCSA General Synod and is often invited as a guest speaker at church gatherings. For several years he was the editor of Die Kerkblad, a publication of the RCSA. The wide range of topics on popular theological articles published from Jorrie's pen (well over a 100) demonstrate his knowledge and understanding of God's Word and his ability to apply the Word in everyday life.

We are grateful that Jorrie's colleagues responded favourably on requests for contributions to the Festschrift dedicated to him. Although there was not an attempt in the planning of the festschrift to elicit contributions around a formulated theme, the theme: 'The text of the Bible: hermeneutics, exegesis and interpretation' would be, to a large extent, amenable to be used as a unifying theme.

Herculaas Frederik (Herrie) van Rooy investigates the use of the Book of Ezekiel in the four Gospels, Acts and in the epistles of Paul, in Hebrews and the general epistles. He finds that, in this corpus, there are only two clear references from the Book of Ezekiel, viz. in 2 Corinthians 6, but that there are quite a number of allusions to Ezekiel. The quotes and allusions to Ezekiel can, according to Van Rooy, mostly rather be linked to the Greek text of Ezekiel than the Masoretic text. He also indicates that the two quotes in 2 Corinthians are used in a typical Pauline manner as part of the series of quotes in which the prophetic texts are used for contemporary application, but in which the original contexts of the quotes are not given due attention. According to Van Rooy the metaphor of the shepherd in Ezekiel 34 and 37 plays an important role in the portrayal of Jesus as the (good) Shepherd.

D.F. Tolmie investigates the epistle to Philemon from a forensic perspective and interprets the letter against the erstwhile legal background. He accepts in his investigation that Onesimus left Philemon's house in order to ask Paul to intercede for him with Philemon. Tolmie discusses Paul's strategy against the background of the relevant legal aspects of slavery. He finds that Paul, in his letter, complied to more than just with the legal requirements. Paul was aware of a more important kind of justice, viz. the justice of God.

Jan A. du Rand stresses the fact that each fragment of narrative information, aimed at making a text comprehensible, is important. In his contribution he deals with the purpose of the narrative asides in the narrative of the book of Revelation. Although he acknowledges that an 'aside' in 
reality is indefinable, he does provide something of a definition when he translates the English 'asides' into 'footnotes' in the narrative text or 'covered', 'non-direct links' 'asides', 'side issues', 'to one side' in order to express the semantic relevance. Du Rand uses the narrative of 4 Ezra as a 'comparable and contemporary literary pole' aimed at a better understanding of the narrative of Revelations. He finds that the asides definitely add semantic value to both the flow and content of the narrative of Revelation and that it is indispensable in terms of the narratological component.

In his contribution, Francois P. Viljoen, indicates the central place taken by the Torah in the Gospel according to Matthew. As stated by Viljoen, Matthew emphasises that the validity of the Torah would endure. Viljoen claims that Jesus' interpretation of the Torah in Matthew differs from that of the Pharisees and the scribes. The righteousness Jesus taught according to Matthew differs, for example, clearly from the righteousness of the Pharisees and scribes.

Paul Kruger investigates the blessings promised to patriarchs and how these blessings abound to others. Kruger finds that there is an 'overflow blessing' for the descendants who are not part of the main line of the covenant as well as for persons with whom the patriarchs associated and for rulers and kings of surrounding nations. He indicates that the patriarchs effected שָׁלוֹ for people who moved within the sphere of influence of the covenant generation and also draws some lines from the study to later prophets and the New Testament.

Sarel P. van der Walt, in his contribution, investigates the anthropological and societal-theoretical viewpoints of departure of the author of Hebrews and takes Hebrews 10:38-39 as a point of departure. After giving attention to the existing anthropological views of the Greek-Hellenist period, Van der Walt indicates how the revelation-historical information in Hebrews offers a corrective about the patterns of thought of the time and how a correct understanding of the gospels provides guidance for societal-theoretical points of departure.

H.G.L. (Eric) Peels indicates in the study of Jeremiah 46:2-12 that Jeremiah in 46:2 refers to the battle of Carchemish in 605 BC. To understand Jeremiah's prophetic interpretation of the events, Peels does a contextual exegesis of the pericope. He understands the pericope in its literary context and against the historical background. Once he has briefly presented the structure and detailed exegesis of 46:10, he suggests the special meaning and intention of the pericope: God in his universal reign makes an end to the lust for power. He does not allow the destruction, as mentioned in 46:6, to pass without punishment.

Gert Breed investigates the service of the elder. He gives special attention to 1 Peter 5:1-5 and the use of the diakon word group in 1 Peter. After investigating the place of 1 Peter 5 within the context of the whole epistle, looked at the link between 1 Peter 5:1-4 and 1 Peter 4:7-1 and done a detailed exegesis of 1 Peter 5:1-4, he comes to the conclusion that Peter in 1 Peter 5:1-4 describes the diakonia of the elders. Based on this research, he suggests some guidelines for the diakonia of the elder according to 1 Peter.

In his article, Raymond Potgieter makes it clear that Anna Reinhard Zwingli's life story had been interwoven with the development of the Reformation in Zurich and the influence it had on her and her family. He indicates that the history of the Reformation cannot be accurately represented without paying attention to the place remarkable women took at that time. Potgieter comes to the conclusion that, although the Reformation led to significant changes for women, it tended to become prescriptive. He indicates that the role of women remains a contentious issue for many in the Christian church.

Cynthia L. Miller-Naudé and Jacobus A. Naudé come to the conclusion that the Bible was compiled by oral tradition and written activity. While using the insights of and debates on the field of Biblical performance criticism, they propose a nuanced description of the relationship between the oral and written culture in the social context of the Bible. They emphasise that these two aspects cannot be separated chronologically or in terms of importance. However, the two aspects cannot be disregarded for the description of a coherent model of the biblical media history. In light of this, Miller-Naudé and Naudé also give an interpretation and translation of the words $\beta i \beta \lambda$ íov and $\beta i \beta \lambda$ os.

Jan van der Watt gives attention to the over-interpretation when dealing with intertextual relations between texts, especially when allusion is assumed. He specifically reflects on the intertextual references to Genesis 28 (the Jacob-BethEl-story) and how it interpretatively influences the interpretation of John 1:51 and whether these interpretations do justice to an understanding of this verse. He regards John 1:51 as a key text in John and accepts that the interpretation of the text has implications for the understanding of the rest of the Gospel, especially for Christology and the doctrine of angels. At the end of the article Van der Watt makes some methodological remarks about the interpretation of a text and the requirements and limits imposed by the text itself.

In his article, C.F.C. Coetzee first gives heartfelt acknowledgement to the work done by Jorrie in the field of reformed hermeneutics. He also concentrates on the hermeneutics of the reformed confessions. He emphasises the close link between Scripture and the confessions, and the resultant authority of these confessions. Coetzee points out that it is important to keep in mind that, although the confessions, as such, already provide explication and commentary on Scripture, these texts themselves must also be interpreted in turn. He provides a number of guidelines that should be applied with a view to the correct understanding and explication of the confessions. 